\title{
Evaluation of hydrocarbon generation potential of source rock using two-dimensional modeling of sedimentary basin: a case study in North Dezful Embayment, Southwest Iran
}

\author{
Ashkan Maleki ${ }^{1} \cdot$ Mohammad Hossein Saberi $^{1}$ (D) $\cdot$ Seyed Ali Moallemi ${ }^{2} \cdot$ Mohammad Hassan Jazayeri $^{2}$
}

Received: 24 January 2021 / Accepted: 28 May 2021 / Published online: 10 June 2021

(c) The Author(s) 2021

\begin{abstract}
Early Cretaceous and Jurassic sequences in the southwestern Iran host some of the largest hydrocarbon reservoirs in the globe. This study is aimed at evaluating the maturity of hydrocarbon fluids, migration paths, and characteristics of Pabdeh, Kazhdumi, Garu and Sargelu source rocks in this region. For this purpose, 27 samples of Pabdeh and Kazhdumi Formations from wells in the northern part of Dezful Embayment were chemically evaluated by Rock-Eval pyrolysis. OpenFlow ${ }^{\mathrm{TM}}$ software was utilized to analyze the burial history, conduct 1D thermal modeling in four oilfields and perform 2D modeling on a section to estimate the maturity and extension of sediments. Results of the 1D modeling showed that the kerogens of Sargelu, Garu and Kazhdumi Formations were properly matured, leading to some hydrocarbon outflow, although the organic matter content of Pabdeh Formation was too immature to produce any hydrocarbon. Based on the plot of hydrogen index (HI) versus Tmax, it was found that the studied formations were dominated by type II kerogen and a mixed species of type II and type III kerogens. Results of the migration path modeling showed some leakage from the Kazhdumi Formation up to an overlying seal that prevented the hydrocarbons from seeping out to surface. The Early and Middle Cretaceous oil systems were found to be connected through geometrical features or faults, with the Kazhdumi Formation separating the two systems. The results further showed the migration of hydrocarbons, at a relatively high rate, into the Abadan Plate through the subKazhdumi reservoirs.The Early and Middle Cretaceous petroleum systems were found to be connected through particular geometry features or possibly faults, with the two systems separated by Kazhdumi Formation. For most part, the intensity of the maturation processes was found to decrease from east to west of the study area.
\end{abstract}

Keywords 1D modeling $\cdot$ 2D modeling $\cdot$ Dezful embayment $\cdot$ Source rock $\cdot$ Migration

\section{Introduction}

Southwestern Iran is among the richest hydrocarbon production areas in the world. Extensive orogenic activity during the Miocene-Pliocene had formed the Zagros Mountains with two uplifts, one in the northern Lorestan and another one in the southern Fars (James and Wynd 1965).

The study area was a structural subarea in the North Dezful just along the Zagros Fold-Thrust Belt. Extended

Mohammad Hossein Saberi

mh.saberi@semnan.ac.ir

1 Department of Petroleum Engineering, Semnan University, Semnan, Iran

2 Exploration Directorate, National Iranian Oil Company, Tehran, Iran over an area of $60,000 \mathrm{~km}^{2}$, North Dezful hosts many large oilfields (Bordenave and Hegre 2005; Jackson and Rise 1981; James and Wynd 1965). More than $90 \%$ of the crude in this area is produced from Asmari limestones (OligoMiocene) and Bangestan Group (Sarvak and Ilam, dated back to Cenomanian-Turonian and Santonian, respectively) (Furst 1990). The limestones of Asmari exhibit very good reservoir quality in most parts of the Dezful Embayment. This favorable reservoir quality is because of the presence of extensive systems of seams and cracks, which are even more extensive near the top of the anticlines. Asmari Formation is capped by the overlying evaporites of Gachsaran Formation (Jackson and Rise 1981). The anticlines within the Dezful Embayment are known to be developed during the Pliocene-Oligocene (Baniasad et al. 2016). Composed dominantly of limestone, Sarvak 
Formation is overlaid by thick layers of Gurpi and Pabdeh marls (James and Wynd 1965).

In the southwestern Iran, the Jurassic succession has driven mass production of oil and gas. It is believed that most of Iran's oil and gas is generated during the Jurassic (e.g. Sargelu Formation) and Cretaceous (Garu and Kazhdumi formations), with the generated hydrocarbons trapped in the reservoirs across the Dezful Embayment and Abadan Plain during the Cretaceous and Cenozoic (Kobraei et al. 2019). Kazhdumi Formation is believed to have served the Dezful Embayment as the main source of hydrocarbon generation. This source rock has been dated back to Albian and hosts type II kerogen (Bordenave 2002; Versfelt 2001). The Middle Jurassic sequence hosts some of the most significant source rocks in in the Zagros Basin, southwestern Iran and eastern Iraq, including the Sargelu Formation with its high total organic carbon (TOC) (Jassin and Goff 2006). Geochemical studies have revealed that the Pabdeh, Kazhdumi, Garu, and Sargelu Formations are the most important source rocks in the Zagros and Persian Gulf basins, feeding the reservoirs in different areas. For example, Pabdeh Formation has produced oil only in the north of Dezful Embayment (North Dezful) while Kazhdumi Formation serves as source in the southwestern Zagros (Dezful Embayment) (Bordenave and Hegre 2005; Karimi et al. 2016a, b). Quantitative geochemical studies and modeling have been carried out across border areas between Dezful Embayment and Abadan Plain (e.g. Ab-Teymour, Mansuri, Susangerd and Band-e-Karkheh fields). On the border between the Abadan Plain and Dezful Embayment, there is much ambiguity in the process of hydrocarbon migration, leaving it yet to be clear that whether the oils of Ab-Teymour, Band-e-Karkheh and Susangerd fields have originated from a source rock within the Dezful Embayment or came from Abadan Plain.

This study aims at investigating the characteristics of rock units from Jurassic (Sargelu Formation), Cretaceous (Garu and Kazhdumi formations) and Paleocene-Oligocene (Pabdeh Formation) in the study area. To describe the quantity, quality and maturity of the organic matter $(\mathrm{OM})$ in the studied formations and estimate the maturation stage of the source rock and hydrocarbon production in the Dezful Embayment, a one-dimensional (1D) model of burial and thermal history was built. The required data was collected from four wells in the Dezful Embayment (Ab-Teymour, Band-e-Karkheh, Mushtaq-East and Ramshir). Subsequently, two-dimensional (2D) modeling was done across a selected section (northeast-southwest) to study hydrocarbon generation, migration, and storage in the study area. Here, we focus on structural features rather than considering possible lateral changes of facies and lithology, which is usually studied for identifying stratigraphic traps.

\section{Geological setting and stratigraphy}

The Zagros Fold-Thrust Belt is part of the Alpine-Himalayan Belt, which is the result of the opening and then closure of the Neo-Tethys Ocean between the Arabian Plate and Iran (Alavi 1994) in the Late Cretaceous (Berberian and King 1981). Extended along a northwest-southeast trend, this belt is about $2000 \mathrm{~km}$ long and starts from the Taurus Mountains in Turkey and covers all the northnortheast of Iraq and southwest of Iran before it terminates in the north of the Strait of Hormuz. In terms of geological history, the belt is known to have experienced long periods of subsidence and sedimentation accompanied by short periods of uplift and hiatus (Alavi 2004). The study area is within the Zagros Fold-Thrust Belt in the south of the so-called Dezful Embayment and North Dezful basin (Karimi et al. 2016a, b). The general structure of Dezful Embayment and the surrounding areas (e.g. upward bending, mountain front bending, Kazerun Fault Zone) as well as the north-south and east-west trends observed can be explained by the faults in the bed rock. The oldest evidence of movement in these linear structures goes back to the Late Cretaceous, although the structures remained active until the Jurassic, Triassic and perhaps even earlier in the Middle Oligocene or Miocene. Dezful Embayment is known to experience a subsidence of 300 to $600 \mathrm{~m}$ though it has been tectonically more stable and less exposed to folding than the neighboring areas (Motiee 1995). Figure 1 shows a location map of the study area and regional hydrocarbon fields. The action of Kazerun (right) and Balaroud faults (left) has greatly contributed to the formation of this embayment.

In terms of geological structure, the Dezful Embayment is composed of a northern part and a southern part separated by the Izeh Fault and the highs of Hindijan. The Dezful Embayment is known to be younger than the Late-Oligocene and Early-Miocene carbonate sediments (Asmari Formation), being a subsidence basin developed since the Middle Miocene to the present (Berberian 1995). In this area, Miocene evaporites provide a good cap rock to the carbonate sediments. Sudden thickness changes in the Gachsaran Formation in this area are associated with folding, faulting, and diapiric activities occurring during and after the deposition. Erosion of the surrounding highlands, especially the Izeh Area in the northeast, has provided more sediment, developing the thickest sedimentary sequence in the Dezful Embayment. Carbonates of Asmari Formation and Bangestan Group are the most important hydrocarbon reservoirs hosted by the embayment. North Dezful is a major zone of hydrocarbon exploration and production in Iran. There are some 60 oilfields in the Dezful Embayment, some of which are so giant, 
Fig. 1 Fields and sections studied in the North Dezful Area. On-dimensional modeling was performed on data from four wells (Ab Teymur, Bande- Karkheh, Mushtaq-East and Ramshir) while the data from two wells were used for $2 \mathrm{D}$ studies (Ahvaz and Mansuri)

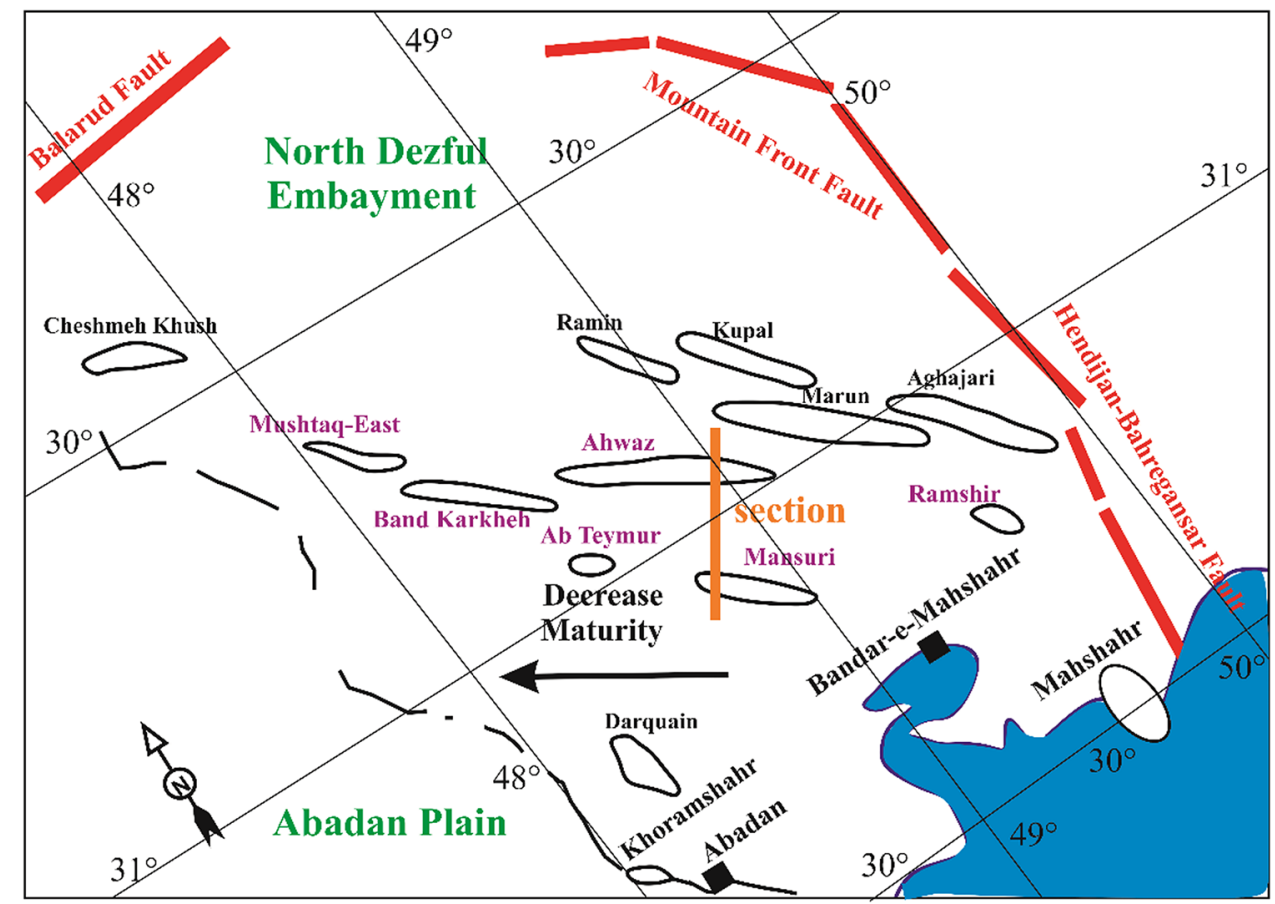

such as Ahvaz, Gachsaran and Bibi Hakimeh fields. Major oilfields in the study area are Tango and Rag Sefid fields (Bordenave 2002; Sherkati and Letouzey 2004).

In the Dezful Embayment, the Kazhdumi Formation has been referred to as the source of the accumulated oils in Bangestan Group. It is the most important source rock for the reservoirs accumulated in Asmari Formation. The organic-rich calcareous shales pertaining to the Kazhdumi Formation, which were deposited in a sealed, intrashelf depression correspond almost exactly to the present-day Dezful Embayment region (Bordenave and Hegre 2005; Karimi et al. 2016a, b). Dated back to Paleocene to Oligocene, Pabdeh Formation exhibits good source rock properties in the Dezful Embayment, especially in the north. Lithologically, the Eocene-Oligocene Pabdeh Formation consists mainly of thin-bedded gray and greenish blue deep-marine pelagic calcareous shale, marl and limestone rich in pelagic micro fauna (Karimi et al. 2016a, b; Alavi 2004; Rabbani and Bagheri Tirtashi 2010). Sargelu Formation underlies Najmeh Formation (below a discontinuity surface) and overlies Alan Formation, with its age estimated as Middle Jurassic. The lithology of this formation is dominantly bituminous gray shale and clayey brown lime with occasional appearance of brown and calcareous dolomites. Dominantly reductive environmental conditions at the time of deposition of Sargelu Formation have made it a source rock of high hydrocarbon generation potential in southwestern Iran (Hosseini and Beldaji 2020; Motiei 1995). Being too deep to drill within the Abadan Plain and Dezful Area, Sargelu Formation is yet to be comprehensively studied in terms of geochemistry. As another effective source rock, Garu Formation is made up of shale and dark brown marl (Arsalan et al. 2015).

In this study, in order to evaluate the maturity of source rocks and hydrocarbon generation and outflow, Ahwaz and Mansuri oilfields were studied at a particular section. Ahwaz Oilfield is located in southwestern Iran. Being in the form of an anticline, it is $67 \mathrm{~km}$ long and $6 \mathrm{~km}$ wide and produces crude oil and gas (i.e. associated gas) at current average rates of 800,000 barrels per day and more than 13 million cubic meters per day, respectively. Mansuri Oilfield is located in the southwestern part of the Zagros Fold-Thrust Belt in the Dezful Embayment, with its crude oil production capacity estimated at 100,000 barrels per day. Figure 2 shows the generic stratigraphic column of the southwestern Iran.

\section{Materials and methods}

Rock-Eval pyrolysis has been widely used in exploratory activities in sedimentary basins. Using this method, it is possible to determine the quality and maturity of organic matter in the source rock and hence estimate hydrocarbon generation potential across the entire petroleum system (Taylor et al. 1998). It works by programmed heating of source rock samples in an oxygen-free neutral environment (helium or nitrogen). The parameters measured in Rock Evil pyrolysis include $\operatorname{Tmax}\left({ }^{\circ} \mathrm{C}\right)$, TOC (wt $\left.\%\right), \mathrm{S} 1, \mathrm{~S} 2$ and S3 (mg HC/g rock). Using these parameters, the hydrogen index $(\mathrm{HI}=100 \times \mathrm{S} 2 / \mathrm{TOC})$, oxygen index $(\mathrm{OI}=100 \times \mathrm{S} 3 /$

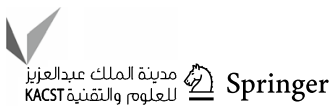


Fig. 2 Stratigraphic column of the studied area in the southwest of Iran. The main sources are indicated by two stars while a single star is used to mark the marginal source rocks

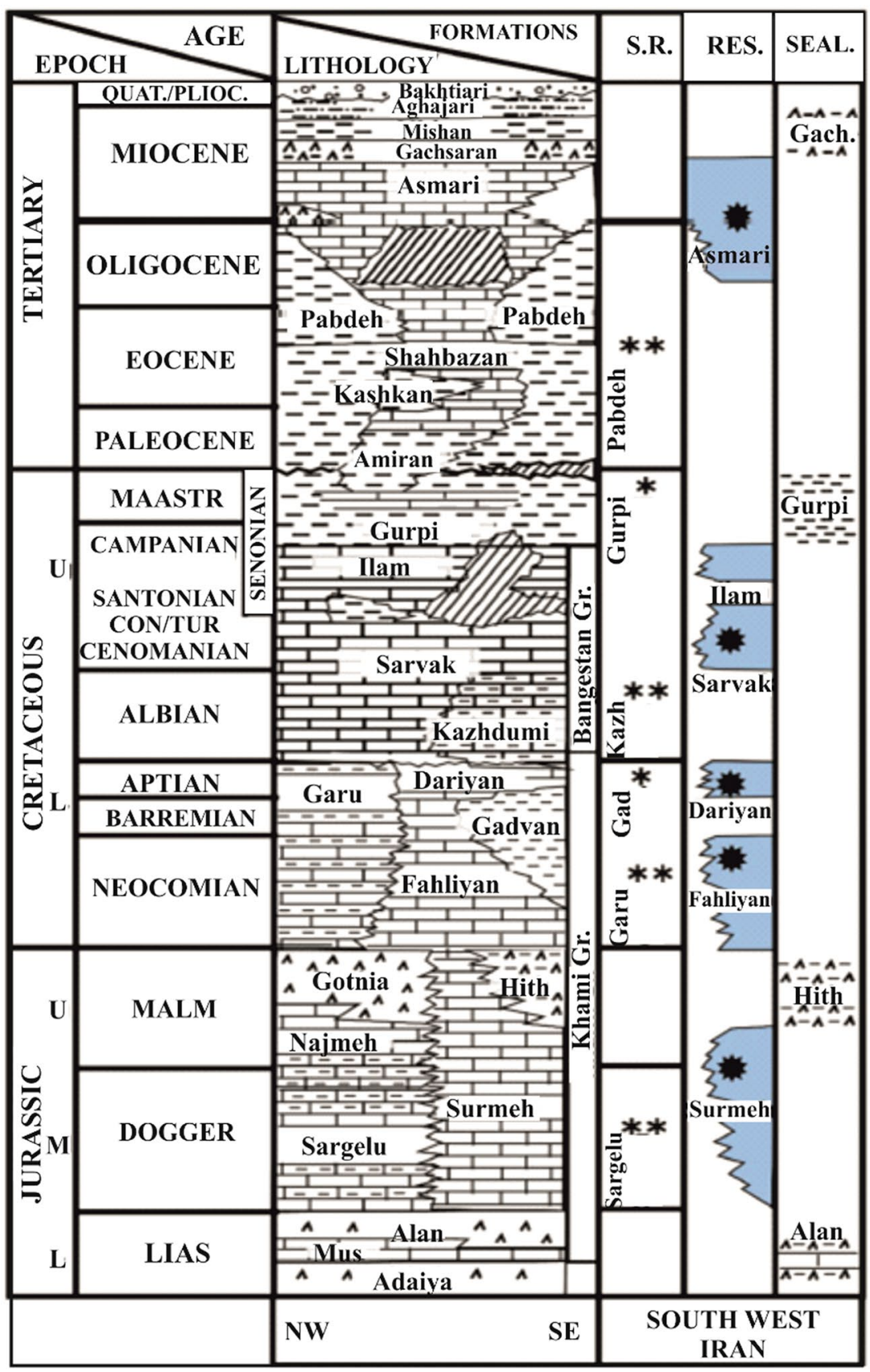

TOC $)$, production index $(\mathrm{PI}=\mathrm{S} 1 /(\mathrm{S} 1+\mathrm{S} 2))$ and hydrocarbon generation potential $(\mathrm{PP}=\mathrm{S} 1+\mathrm{S} 2)$ can be calculated. In this study, 27 samples of Pabdeh and Kazhdumi formations were subjected to Rock-Eval pyrolysis, with the results shown in Table1.

Basin modeling and hydrocarbon system assessment try to formulate a dynamic predictive model of the geological processes occurred during the evolution of a sedimentary basin (Baniasad et al. 2016; Hantschel and Kauerauf 2009). Modeling tools are widely used in oil exploration work and can help explorationists attain a better understanding of the petroleum systems and the interrelationships among hydrocarbon reserves (Hakimi et al. 2017). Such models have been developed to measure and simulate various processes occurred during the formation and evolution of a sedimentary basin (Baniasad et al. 2016), where the entire package of strata from the oldest to the youngest are simulated (Baur et al. 2010; Beha et al. 2008; Noeth et al. 2002).

Basin modeling can be performed one-dimensionally (1D) or two-dimensionally (2D). For this purpose, we use the geological data acquired along one or more wells, per seismic surveys, or upon structural studies along different sections to simulate the burial history and maturity of the studied section. The first step in basin modeling is to create 
Table 1 Input geochemical data into the model

\begin{tabular}{|c|c|c|c|c|c|c|c|c|c|c|c|}
\hline Field & Formation & Depth (m) & TOC (\%) & $\begin{array}{l}\mathrm{S} 1 \text { (mg } \\
\mathrm{HC} / \mathrm{g} \text { rock) }\end{array}$ & $\mathrm{S} 2$ & S3 & $\operatorname{Tmax}\left({ }^{\circ} \mathrm{C}\right)$ & HI & OI & PI & PP \\
\hline \multirow[t]{11}{*}{ Ab Teymur } & Pabdeh & 2610 & 1.1 & 0.47 & 1.09 & 5.71 & 307 & 99.09 & 519.09 & 0.30 & 1.56 \\
\hline & Pabdeh & 2630 & 0.49 & 0.59 & 0.53 & 2.43 & 296 & 108.16 & 495.92 & 0.53 & 1.12 \\
\hline & Pabdeh & 2680 & 1.22 & 2.95 & 2.73 & 1.22 & 431 & 223.77 & 100 & 0.52 & 5.68 \\
\hline & Pabdeh & 2710 & 7.16 & 8.39 & 35.97 & 1.81 & 412 & 502.37 & 25.28 & 0.19 & 44.36 \\
\hline & Kazhdumi & 4100 & 4.62 & 13.87 & 16.63 & 0.83 & 445 & 359.96 & 17.97 & 0.45 & 30.5 \\
\hline & Kazhdumi & 4120 & 3.6 & 7.2 & 15.38 & 1 & 441 & 427.22 & 27.78 & 0.32 & 22.58 \\
\hline & Kazhdumi & 4140 & 3.31 & 0.24 & 16.44 & 1.18 & 443 & 496.68 & 35.65 & 0.01 & 16.68 \\
\hline & Kazhdumi & 4150 & 1.62 & 2.09 & 5.04 & 1.31 & 437 & 311.11 & 80.86 & 0.29 & 7.13 \\
\hline & Kazhdumi & 4225 & 3.42 & 3.49 & 8.31 & 0.67 & 433 & 242.98 & 19.59 & 0.30 & 11.8 \\
\hline & Kazhdumi & 4260 & 2.23 & 2.18 & 4.74 & 0.92 & 440 & 212.56 & 41.26 & 0.32 & 6.92 \\
\hline & Kazhdumi & 4280 & 1.12 & 1.26 & 4.11 & 1.58 & 437 & 366.96 & 141.07 & 0.23 & 5.37 \\
\hline \multirow[t]{3}{*}{ Ahwaz } & Kazhdumi & 4440 & 2.21 & 0.43 & 10.53 & 0.67 & 440 & 476.47 & 30.32 & 0.04 & 10.96 \\
\hline & Kazhdumi & 4540 & 1.45 & 0.25 & 2.97 & 0.77 & 444 & 204.83 & 53.10 & 0.08 & 3.22 \\
\hline & Kazhdumi & 4640 & 1.37 & 0.31 & 5.45 & 0.96 & 445 & 397.81 & 70.07 & 0.05 & 5.76 \\
\hline \multirow[t]{3}{*}{ Band-e-Karkheh } & Pabdeh & 3320 & 2.23 & 0.64 & 10.02 & 2.18 & 427 & 449.33 & 97.76 & 0.06 & 10.66 \\
\hline & Pabdeh & 3355 & 3.38 & 0.76 & 13.16 & 2.81 & 421 & 389.35 & 83.14 & 0.05 & 13.92 \\
\hline & Pabdeh & 3375 & 1.37 & 0.31 & 2.4 & 2.19 & 433 & 175.18 & 159.85 & 0.11 & 2.71 \\
\hline \multirow[t]{7}{*}{ Mansuri } & Pabdeh & 2880 & 2.31 & 0.88 & 1.67 & 3.23 & 424 & 72 & 140 & 0.35 & 2.55 \\
\hline & Pabdeh & 2920 & 1.02 & 0.79 & 1.22 & 0.61 & 430 & 119 & 60 & 0.39 & 2.01 \\
\hline & Kazhdumi & 4120 & 6.25 & 4.85 & 10.2 & 1.37 & 439 & 163 & 22 & 0.32 & 15.05 \\
\hline & Kazhdumi & 4160 & 6.1 & 142.5 & 222.4 & 1.09 & 440 & 361 & 18 & 0.39 & 364.9 \\
\hline & Kazhdumi & 4240 & 3.2 & 78.25 & 120.5 & 0.70 & 439 & 370 & 22 & 0.39 & 198.7 \\
\hline & Kazhdumi & 4320 & 3.48 & 4.78 & 6.25 & 1.77 & 439 & 179 & 51 & 0.43 & 11.03 \\
\hline & Kazhdumi & 4400 & 2.72 & 3.75 & 5.12 & 1.95 & 441 & 188 & 72 & 0.42 & 8.87 \\
\hline \multirow[t]{3}{*}{ East-Mushtaq } & Pabdeh & 3840 & 7.79 & 20.43 & 36.22 & 0.87 & 419 & 464 & 11.16 & 0.39 & 56.65 \\
\hline & Pabdeh & 3890 & 1.23 & 3.43 & 2.49 & 0.5 & 432 & 202 & 40.65 & 0.57 & 5.92 \\
\hline & Pabdeh & 3908 & 2.44 & 7.28 & 3.73 & 0.43 & 430 & 152.8 & 17.62 & 0.66 & 11.01 \\
\hline
\end{tabular}

a hypothetical model of the geological history of the well or area under study in which a sequence of geological events or layers such as sedimentation, interruption, and erosion are defined over a period of time (millions of years ago). To simulate a sedimentary basin, one should define the physical and thermal characteristics of different layers including the original and current thicknesses, lithology, current porosity, cementation, and fractures and faults; add to this the physical and thermal characteristics along the boundaries, including temperature, water-sediment boundary at the time of deposition, and the current and past heat flows. In this study, 1D modeling was performed using the data from four wells, namely Ab-Teymour, Band-e-Karkheh, Mushtaq-East and Ramshir, drilled in the Dezful Embayment. Then, 2D modeling was further performed to determine the migration paths and the location of possible hydrocarbon accumulations based on the source rocks and migration paths across a selected section (northeast-southwest, shown in Fig. 1) in the Dezful Embayment. OpenFlow ${ }^{\mathrm{TM}}$ Software was utilized to model and interpret the history of generation, migration and accumulation of hydrocarbons. At the northeast-southwest section, we considered Tertiary (with Pabdeh as source rock), Cretaceous (with Kazhdumi and Garu as source rocks) and Jurassic petroleum systems (with Sargelu as source rock). As far as the hydrocarbon sourcing is concerned, these are the most interesting formations in the Dezful Embayment (Karimi et al. 2016a, b). The well selection was done to have the maximum drilling depth and availability of hydrocarbon maturation and production data.

For 2D modeling across the northeast-southwest section, we began with entering the geological information of the section (e.g. different rock layers, age information, and fault information) into the OpenFlow ${ }^{\mathrm{TM}}$ Software. We then introduced into the model, through the Age Assignment and Facies Definition module, the stratigraphic data (e.g. layer names, top depths and ages), lithologic information, erosion and hiatus information, and the position of each layer in the petroleum system, not to mention the geochemical information related to the source formations. This was followed by entering the initial hydrogen index (HI, based on the built-in 
geochemistry library of the software), total organic carbon (TOC), and the kerogen type. The lithology information was determined by compiling the well data, existing lithological maps, and the stratigraphic column of the current sediments down to the bed rock upon applying the effect of the layer ages.

An important objective of thermal modeling is to measure the accuracy of the initial geological model and hence improve it by adjusting various parameters. The data required for $2 \mathrm{D}$ modeling can be extracted from seismic and structural sections, outcrop studies and geological data. Petrological information and chronology of the layers were retrieved from well reports (prepared by Exploration Directorate of National Iranian Oil Company, NIOC Exp.). Geochemical data on the source rock (e.g. TOC, HI, and kerogen type) were extracted from the reports published by the Geochemistry Department of the NIOC Exp. In order to achieve more accurate results, we focused on the hydrocarbon generation from Kazhdumi, Pabdeh, Garu and Sargelu formations only. For 2D modeling, a northeast-southwest cross section was designed in the OpenFlow ${ }^{\mathrm{TM}}$.

\section{Results and discussion}

In this study, 1D modeling of wells located in Ab-Teymour, Band-e-Karkheh, East-Mushtaq and Ramshir fields in the north of Dezful Embayment was performed. Calibration establishes an optimal fit between the measured parameters and the model and plays an important role in effective modeling of the studied phenomenon. The best calibration results were obtained when a constant heat flux (HF) in the range of 44 to $50 \mathrm{~mW} / \mathrm{m}^{2}$ was considered along different wells. Measured values of vitrinite temperature and reflectance were used to check the modeling accuracy.

\section{Rock-Eval pyrolysis}

S1 (mg HC/g rock) measures the amount of free hydrocarbons that can be volatilized out of the rock without cracking the kerogen. S2 shows the hydrocarbon yield upon cracking of kerogen, representing the remaining hydrocarbon generation potential of the source rock (Magoon and Dow 1994). S1 values of the Kazhdumi Formation in the north of Dezful Embayment ranged from 0.24 to $142.5 \mathrm{mg} \mathrm{HC} / \mathrm{g}$ rock, with an average value of $17.69 \mathrm{mg} \mathrm{HC/g}$ rock. Pabdeh Formation exhibited S1 values in the range of 0.31 to $20.43 \mathrm{mg}$ $\mathrm{HC} / \mathrm{g}$ rock, with an average value of $3.91 \mathrm{mg} \mathrm{HC/g}$ rock (Table 1). As an output of Rock-Eval pyrolysis, Tmax provides great insights into thermal maturity of the analyzed sample. In this work. Samples from Kazhdumi and Pabdeh Formations exhibited Tmax values in the ranges of 433-445 ${ }^{\circ} \mathrm{C}$ and $296-439^{\circ} \mathrm{C}$, respectively (Table 1). Tmax vs. HI plot reveals that most samples of the Kazhdumi Formation were thermally mature while those of the Pabdeh Formations were either immature or in early maturation stages (Fig. 3).

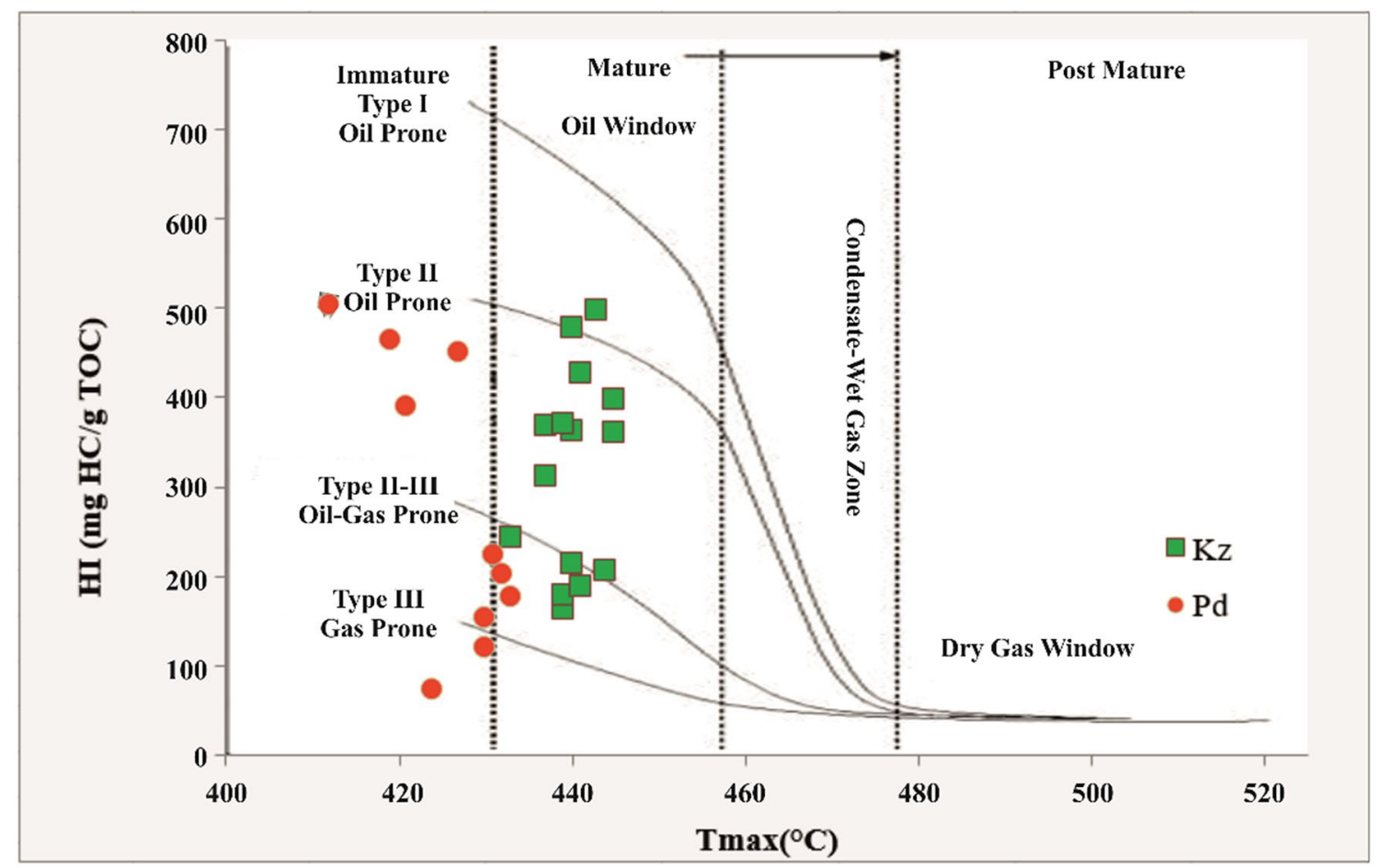

Fig. 3 Plot of Tmax vs. HI showing the types of kerogen and maturity of the studied samples in the north of Dezful Embayment 
The findings show that the Kazhdumi Formation in the study area (north of Dezful Embayment) is within the oil window, making it a major source rock in the region, while Pabdeh Formation was not buried deep enough to reach the required maturity for producing hydrocarbons although it has produced very small amounts of hydrocarbon in some areas. Based on the Tmax vs. HI plot, it was determined that the studied formations were dominated by type II and a mixed species of type II and type III kerogens (Fig. 3).

Studies on Garu and Sargelu Formations in the North of Dezful Embayment area indicated that these formations serve as source rocks with moderate to high hydrocarbon generation potentials. According to these studies, the Garu Formation was dominated by type II and a mixed species of type II and type III kerogens, while Sargelu Formation contained, for most part, a mixture of type II and type III kerogens. The Garu Formation was found to possess more gas generation potential rather than oil production potential, and Sargelu Formation was found to be capable of gas generation only. According to the results of geochemical studies, Pabdeh Formation was found to be less mature than other source rocks and hence was not the main source rock in this area (Asadi et al. 2010; Hosseini and Beldaji 2020).

\section{D modeling}

In the studied area, the Ab-Teymour well has been drilled into a maximum depth of $5040 \mathrm{~m}$, reaching the Lower Cretaceous deposits of the Fahlian Formation. To achieve more accurate modeling results, the well was extrapolated by defining pseudo-layers to reach the top of the bed rock. For this purpose, information from adjacent wells was used to estimate the tops of Garu and Sargelu formations. Used to calibrate the model, the measured temperature and vitrinite reflectance data in the Ab-Teymour well are shown in Table 2a. Based on this table and upon testing different models, the corresponding HF, which is most consistent with the current bottom-hole temperature (BHT), was taken at 48 $\mathrm{mW} / \mathrm{m}^{2}$. Figure $4 \mathrm{a}$ shows the maturity diagram along the $\mathrm{Ab}$-Teymour well in terms of vitrinite reflectance. At this well, some $160 \mathrm{~m}$ of Aghajari Formation was eroded out, as per seismic data. For all fields, erosion was estimated based on seismic data. This was done by taking the maximum layer thickness at a syncline as reference and measuring the thickness at the respective anticline to identify the lost part, unless evidence of hiatus was observed on the respective anticline/syncline. According to the results of the model, Sargelu and Garu Formations exhibited vitrinite reflectance at $1.4 \%$, making them placed in the wet gas production window. Kazhdumi Formation, with a vitrinite reflectance of $0.85 \%$, was found to be in the oil window, and Pabdeh Formation, with a vitrinite reflectance of $0.58 \%$, was just in the beginning of the oil window.
Table 2 Temperature and vitrinite reflectance data for model calibration

\begin{tabular}{|c|c|c|c|}
\hline Field & Depth (m) & $\begin{array}{l}\text { Vitrinite } \\
\text { reflectance } \\
(\%)\end{array}$ & Temperature $\left({ }^{\circ} \mathrm{C}\right)$ \\
\hline \multirow{17}{*}{$\begin{array}{l}\text { a } \\
\text { (Ab-Teymour) }\end{array}$} & 2820 & 0.57 & - \\
\hline & 2851 & 0.59 & - \\
\hline & 2865 & 0.6 & - \\
\hline & 3159 & - & 107.2 \\
\hline & 3434 & - & 112.7 \\
\hline & 4233 & 0.62 & - \\
\hline & 4265 & 0.66 & - \\
\hline & 4281 & 0.75 & - \\
\hline & 4473 & 0.64 & - \\
\hline & 4495 & 0.65 & - \\
\hline & 4510 & 1.12 & - \\
\hline & 4513 & - & 140.4 \\
\hline & 4521 & 1.15 & - \\
\hline & 4545 & - & 141.5 \\
\hline & 4593 & - & 142.6 \\
\hline & 4710.2 & - & 146.6 \\
\hline & 4759 & - & 147.5 \\
\hline \multirow{3}{*}{$\begin{array}{l}\text { b } \\
\text { (Band-e-Karkheh) }\end{array}$} & 2831 & - & 87.77 \\
\hline & 3636 & - & 108.66 \\
\hline & 3706 & - & 111.11 \\
\hline \multirow{5}{*}{$\begin{array}{l}\text { c } \\
\text { (Mushtaq-East) }\end{array}$} & $32,670.5$ & - & 96.66 \\
\hline & $39,070.5$ & 0.64 & 109.44 \\
\hline & $40,090.5$ & 0.6 & 111.66 \\
\hline & $44,770.5$ & - & 122.77 \\
\hline & $47,270.5$ & - & 128.88 \\
\hline \multirow{3}{*}{$\begin{array}{l}\text { d } \\
\text { (Ramshir) }\end{array}$} & 2773 & - & 96.67 \\
\hline & 3680 & - & 121.67 \\
\hline & 3723 & - & 122.78 \\
\hline
\end{tabular}

The Band-e-Karkheh well was drilled into a maximum depth of $4285 \mathrm{~m}$, reaching the Upper Cretaceous Sarvak Formation. With no vitrinite reflectance data from this well, we only used well temperature data to calibrate the model (Table $2 \mathrm{~b}$ ). The corresponding maturity diagram indicates that the Aghajari Formation has not been eroded at this well. At the Band-e-Karkheh well, the Sargelu and Garu formations showed vitrinite reflectance of $1.4 \%$ and $1.3 \%$, respectively, situating them in the gas window. Finally, vitrinite reflectance of Kazhdumi and Pabdeh Formations was about $0.87 \%$ and $0.63 \%$, respectively, placing them in the middle and early oil window, respectively (Fig. 4b).

Drilled into a maximum depth of $4994 \mathrm{~m}$, Mushtaq-East well penetrated through the Upper Cretaceous Sarvak Formation. In the Mushtaq-East Field, which is relatively far from the other studied fields, Aghajari Formation was found to have some $200 \mathrm{~m}$ of its original thickness eroded away. The measured values of temperature and vitrinite reflectance

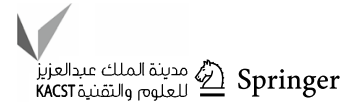




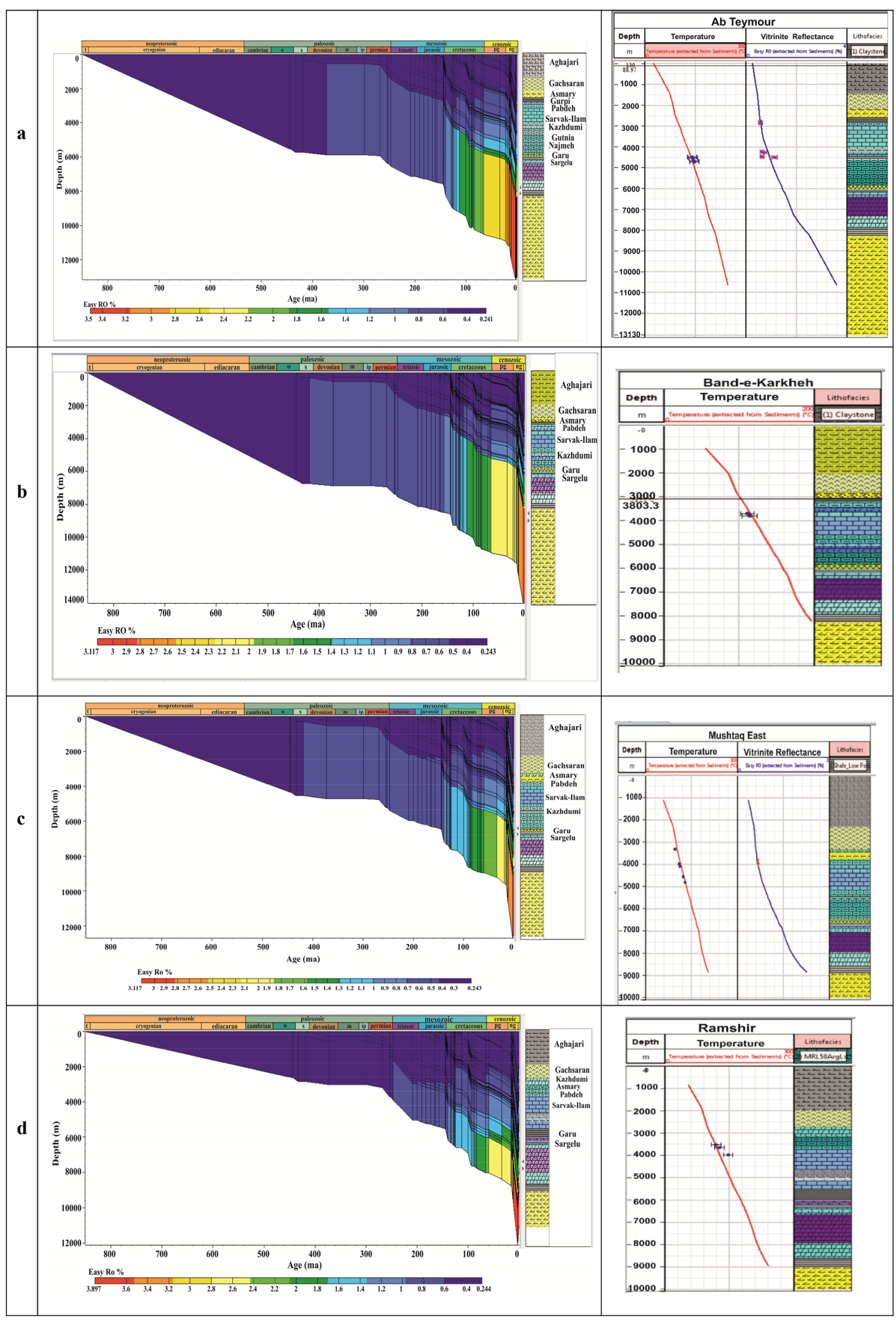


४Fig. 4 Burial history charts with thermal models (left) and temperature-depth and vitrinite reflectance-depth plots to fit the model results to the measured data (right)

were used to calibrate the model according to Table $2 \mathrm{c}$, ending up with a very good agreement between the measured data and the modeling results. The maturity diagram of this well (Fig. 4c) shows that the Sargelu Formation was located at the end of the oil window with a vitrinite reflectance of $1.25 \%$, while Garu, Kazhdumi and Pabdeh Formations were in the middle of oil window with vitrinite reflectance values of $1.15,0.9$ and $0.65 \%$, respectively.

In the Ramshir Field, the Aghajari Formation was found to have some $1100 \mathrm{~m}$ of its original thickness eroded away. With a maximum drilling depth of $4660 \mathrm{~m}$, the field was studied down to Sarvak Formation. Given the unavailability of vitrinite reflectance data, only temperature data was used for calibrating the model in this field, leading to a good agreement (Table $2 \mathrm{~d}$ ). Figure $4 \mathrm{~d}$ shows the maturity of the studied formations at the studied well in Ramshir Field. As shown in the figure, Sargelu and Garu formations exhibited vitrinite reflectance values of $1.8 \%$ and $1.7 \%$, respectively, categorizing them in the wet gas production window. Moreover, Kazhdumi Formation, with a vitrinite reflectance of $1.17 \%$, was in the beginning of the gas window. Finally, Pabdeh Formation showed a vitrinite reflectance of $0.74 \%$, which showed that the formation was in the oil window. According to the results of 1D modeling, the studied source rocks were most matured in Ramshir Field, possibly because of their deeper burial depth in this field.

\section{D modeling}

As mentioned earlier, 2D modeling was performed on a selected section (with a northeast-southwest trend) in the study area. The software compiled the seismic, stratigraphic and geological interpretation data to carry out multidimensional simulations of HF, fluid flow and oil migration in the sedimentary basin. As outputs, the 2D modeling gives estimations of the oil/gas generation from the source rock, migration through the carrier rock, and accumulation in the reservoir rock. It further returns the formation pressure history. As shown in Fig. 1, the selected section cut through Ahwaz and Mansuri fields, where the well data were available to evaluate the modeling accuracy. Validation of the modeling results at well location against the well data indicated a good agreement (Table 3). Simultaneous calibration of temperature and vitrinite reflectance and the uniformly increasing trend of vitrinite reflectance with depth highlighted the mild tectonic history of the region (Fig. 5).

The drilling of Ahwaz well has been completed after reaching a depth of $5000 \mathrm{~m}$ in Fahlian Formation. To achieve more accurate results in modeling, the layers were extrapolated to the basement. According to Fig. 6a, the deepest sediments are related to the Lower Fahlian Formation, i.e. Lower Cretaceous, some 145 million years ago. According to Fig. 6a, the Middle-Jurassic Sargelu Formation exhibited a vitrinite reflectance of $1.50 \%$ and was found to be within gas production window. In the Middle Cretaceous, the same formation (Sargelu) was found to enter the oil window, with the largest amounts of oil produced from this formation during the Upper Cretaceous. Further at this well, the Garu Formation showed a vitrinite reflectance of $1.40 \%$, placing it is gas production window. But previously, this formation was found to have entered the oil window in the Upper Cretaceous. With a vitrinite reflectance of $0.98 \%$, the Kazhdumi Formation was found to be in the oil window since after the Eocene. The Pabdeh Formation showed a vitrinite reflection of as low as $0.63 \%$, situating it in early stages of oil production where the generation rate is very low.

Completed at a depth of $5000 \mathrm{~m}$, Mansuri well penetrated down to the Lower Fahlian Formation dated back to some 145 million years ago (Fig. 6b). According to the modeling results, Middle-Jurassic Sargelu Formation at Mansuri Well is currently located at a depth of 5773 to $5743 \mathrm{~m}$. Based on Fig. 6b, the Sargelu Formation had reached a vitrinite reflectance of $0.55 \%$ some 100 million years ago from when it began to produce hydrocarbons. Presently, this formation has a vitrinite reflectance of $1.25 \%$, implying its position at the end of the oil production window. At this well, the Garu Formation occurred at a depth of 5523 to $5563 \mathrm{~m}$, entering the oil production window in the Upper Cretaceous. At present, this formation exhibits a vitrinite reflectance of $1.15 \%$, keeping it in the oil window. Presently occurred at a depth of 4146-4352 m at Mansuri well, Kazhdumi Formation was dated back to the Middle Cretaceous. It has been found to enter the oil window in the Middle Miocene with a vitrinite reflectance of $0.55 \%$, and is currently at the peak of oil production window with a vitrinite reflectance of $0.37 \%$. Focusing on Pabdeh Formation, Fig. $6 \mathrm{~b}$ indicates that the vitrinite reflectance had reached $0.55 \%$ some 4 million years ago and is now at $0.58 \%$, locating the formation in the beginning of the oil production window. Like the Pabdeh Formation at Ahwaz well, hydrocarbon production It has been insignificant.

Regarding its significant role in the maturity of the source rock and hydrocarbon production and migration, temperature is an important parameter in any geochemical assessment. Basin modeling provides a unique opportunity to study temperature regimes in space and time. Accurate determination of the temperature history is possible only if the heat transfer process is examined in terms of real physical dynamics under the given boundary conditions in the sedimentary basin and its evolution over time. The temperature is also important as it affects the physical properties

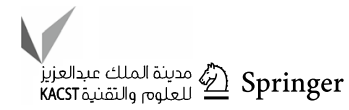


Table 3 Temperature and vitrinite reflectance data for calibrating the 2D models of Ahwaz and Mansuri fields

\begin{tabular}{|c|c|c|c|c|}
\hline Field & Depth (m) & $\begin{array}{l}\text { Vitrinite } \\
\text { reflectance } \\
(\%)\end{array}$ & Depth (m) & Temperature $\left({ }^{\circ} \mathrm{C}\right)$ \\
\hline \multirow[t]{16}{*}{ Mansuri } & 1320 & 0.31 & 2200 & 81.39 \\
\hline & 1482 & 0.38 & 3215.2 & 107.22 \\
\hline & 1940 & 0.33 & 3310 & 109.44 \\
\hline & 2000 & 0.33 & 3490.2 & 112.78 \\
\hline & 2770 & 0.36 & 4476.8 & 135.56 \\
\hline & 2780 & 0.34 & 4571 & 137.22 \\
\hline & 2920 & 0.4 & & \\
\hline & 3120 & 0.47 & & \\
\hline & 3600 & 0.57 & & \\
\hline & 3910 & 0.44 & & \\
\hline & 4090 & 0.55 & & \\
\hline & 4120 & 0.6 & & \\
\hline & 4140 & 0.56 & & \\
\hline & 4485 & 0.55 & & \\
\hline & 4510 & 0.75 & & \\
\hline & 4515 & 0.73 & & \\
\hline \multirow[t]{6}{*}{ Ahwaz } & & & 2712 & 88.333 \\
\hline & & & 3377 & 106.6667 \\
\hline & & & 3771.1 & 123.8889 \\
\hline & 4372 & 0.64 & 4662.5 & 136.6 \\
\hline & & & 4770 & 141.1 \\
\hline & & & 4865 & 142.77 \\
\hline
\end{tabular}

of sediments and hydrocarbon fluids. As a result, many processes occurred during the evolution of a basin, such as compaction and fluid flow, are directly controlled by temperature. Therefore, a realistic reconstruction of the temperature history is critical for modeling basin evolution and understanding the corresponding highly complex processes and their interactions during basin development (Welte et al. 1997).

In the basin modeling, spatial modeling of temperature variations is of paramount importance as it reveals thermal properties of different rock units and their changes across the underground space. One of the most difficult and sensitive tasks in the basin modeling is to assign reliable values to various geological units comprising the modeling domain.

The modeling results showed that the maximum temperature recorded in the Pabdeh Formation was about $90{ }^{\circ} \mathrm{C}$, which was less than enough, given the shallow burial depth of the formation, to make the rock unit so mature that hydrocarbon can be produced. Kazhdumi and Garu Formations were found to have experienced temperatures in the ranges of $90-105^{\circ} \mathrm{C}$ and $160-180^{\circ} \mathrm{C}$, respectively, with Sargelu Formation underwent a maximum temperature of $173{ }^{\circ} \mathrm{C}$ (Fig. 7).

Figure 8 shows the maturity of different formations in the study area in terms of vitrinite reflectance. The figure suggests that the formations had their maturity increased with depth in the synclines. According to the results, the eastern part of the study area had just stepped in the oil window, where the Kazhdumi Formation showed a vitrinite reflectance of about $0.8 \%$ on the ridge of the anticline. However, with increasing the depth (synchronization), this value reached as high as $1.3 \%$, making the respective rock units beyond the oil window. The Garu and Sargelu Formations were found to be more mature in synclines rather than anticlines, although the TOC of the Pabdeh Formation was not mature enough to produce hydrocarbons, possibly due to the shallow burial depth. Results of the present maturity model showed a generally decreasing
Fig. 5 Vitrinite reflectancedepth and temperature-depth diagrams for fitting the models to the measured data

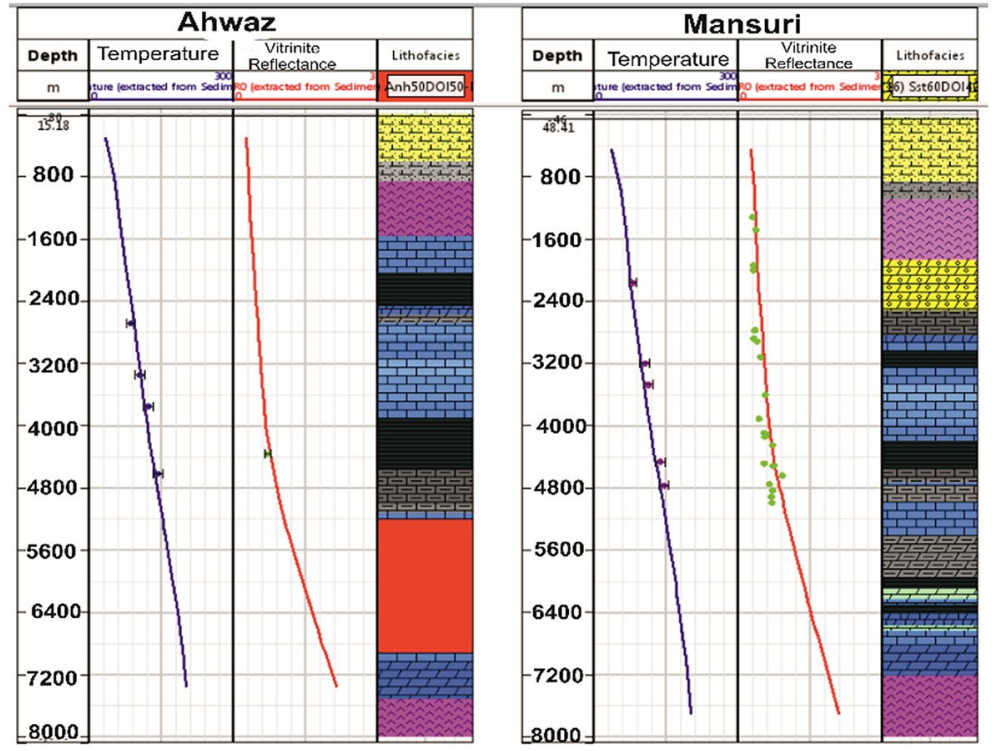




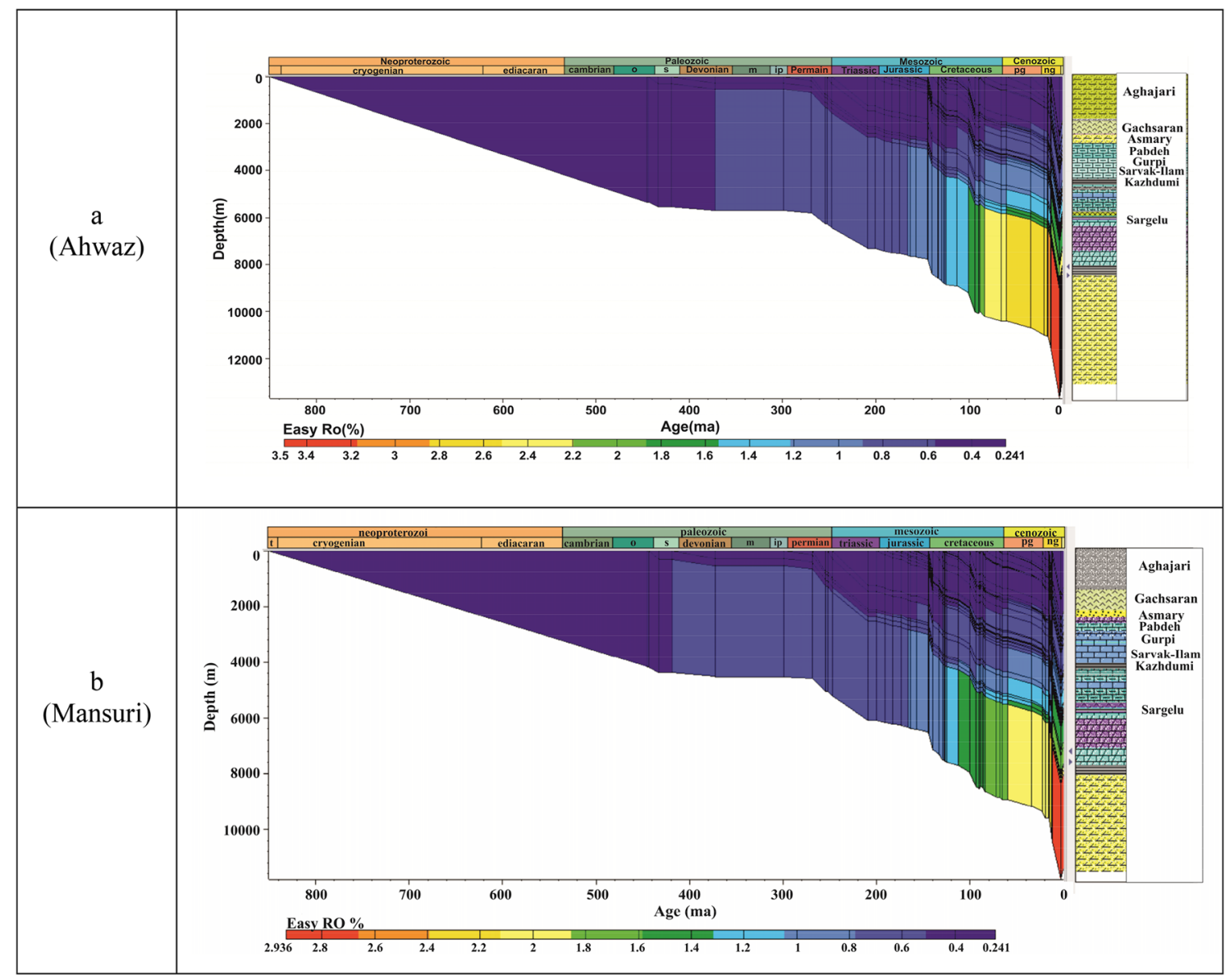

Fig. 6 Burial history charts of Ahwaz a and Mansuri b wells

trend of maturity in the source rocks as one moved from the Dezful Embayment to the Abadan Plain.

More intensive heat fluxes were observed wherever the bed rock occurred at a shallower depth. The increase in the thickness of sediments in the east of the model increased the depth of burial compared to the east, further contributing to the maturity of the source rocks on this side of the model. Also, based on the results of the 1D modeling of the four wells located in the Ab-Teymour, Band-e-Karkheh, Mushtaq-East and Ramshir fields (in the vicinity of the studied fields, namely Ahwaz and Mansuri) and also those of the 2D modeling, it could be stipulated that Ramshir Field in the east of the section was the most mature field in the region, with the vitrinite reflectance values of the studied source rocks decreased as one moved to the west toward the Ab-Teymour, Band-e-Karkheh and Mushtaq-East fields (Fig. 1). The measured values of the vitrinite reflectance at wells indicated a decrease in the maturity of the source formations as one went from east to the west. In fact, the increased heat flux and the depth of burial at the present time contribute to higher maturity of the source rocks in the east.
An important outcome of basin modeling is the identification (or prediction) of hydrocarbon migration paths and accumulations within the petroleum system. Figure 9 presents the identified migration paths through which the hydrocarbons migrated from source rock to reservoir rock where they were accumulated. The hydrocarbon generation and migration processes can be explained by Darcy's law and Arrhenius kinetic law, respectively (Schneider 2003; Ungerer et al. 1990). Our migration model showed a possibly large accumulation of hydrocarbon beneath the Kazhdumi Formation. At depths below the Kazhdumi Formation, such hydrocarbon accumulation was predicted to be located in between the studied fields, while shallower reservoirs (i.e. above Kazhdumi Formation) contained such accumulations within them. The results of 2D modeling indicated that the petroleum systems developed during the Early and Middle Cretaceous were occasionally connected via faults and special geometry features, with the two separated by the Kazhdumi Formation, which not only served as the source rock for the overlying layers but also sealed the underlying strata as cap rock. This formation was found to have reached the peak of oil production window in the depression area 


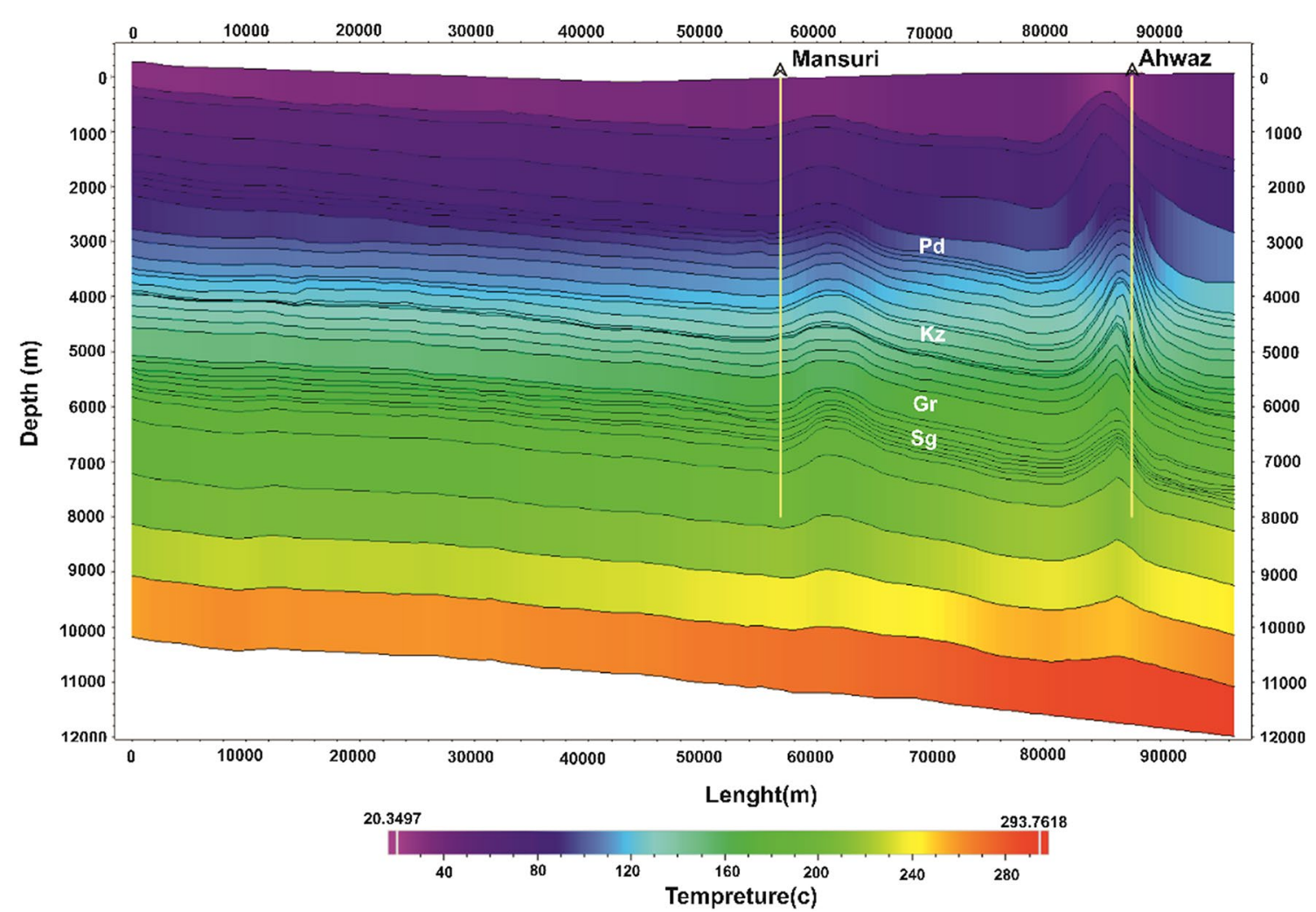

Fig. 7 Modeling results in terms of temperature profile along the northeast-southwest section

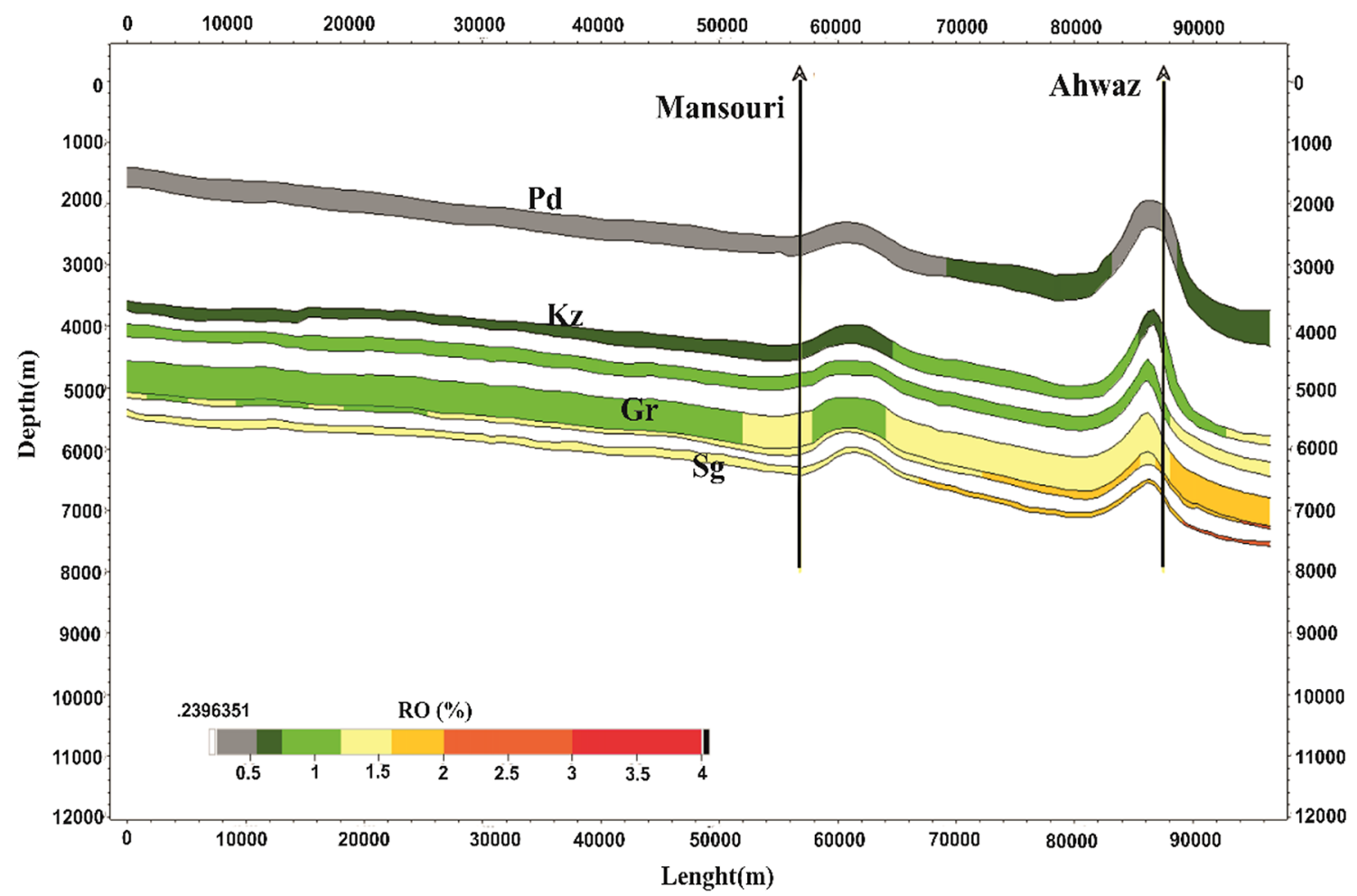

Fig. 8 Plot of the vitrinite reflectance versus time along the studied section 


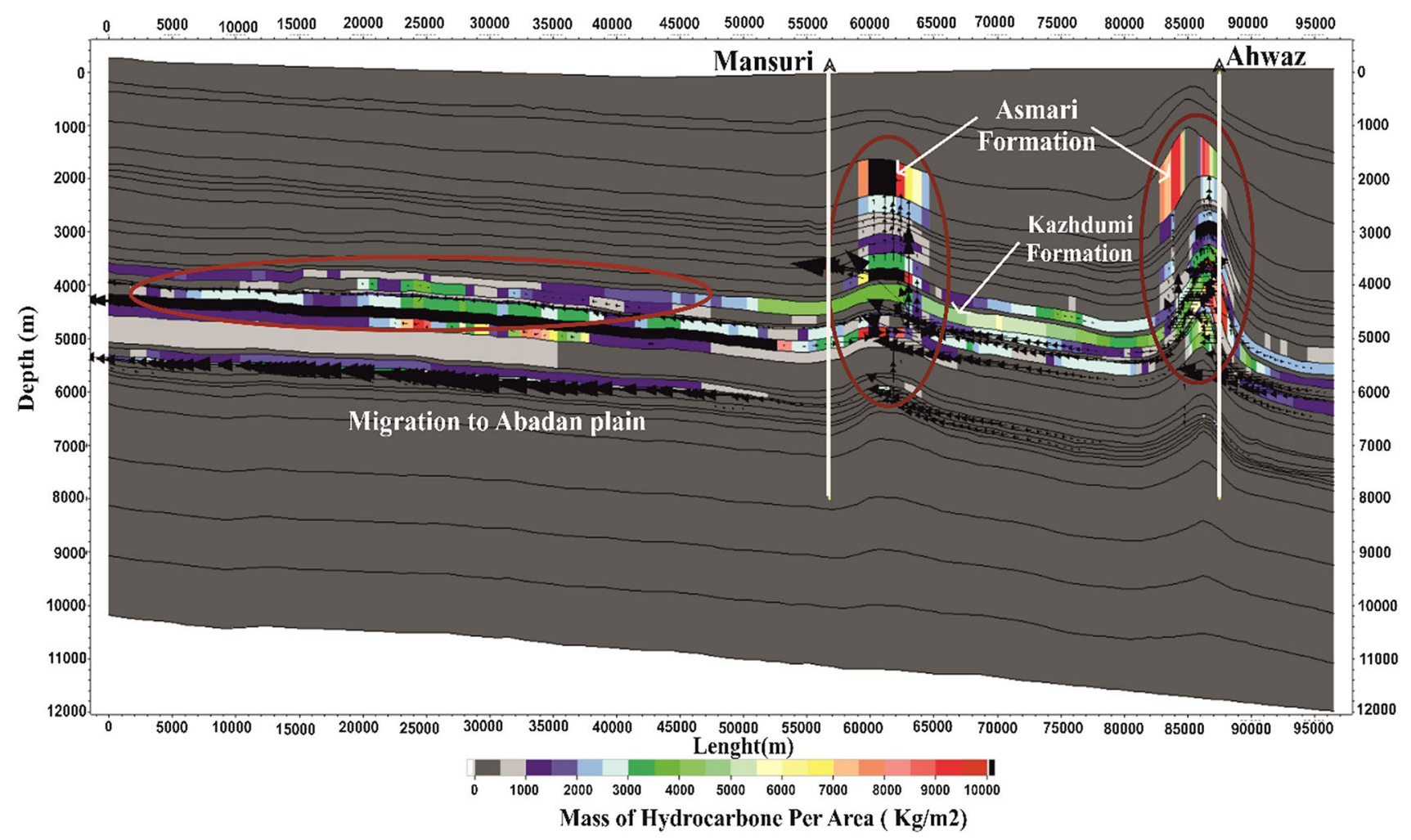

Fig. 9 An output of the hydrocarbon migration and accumulation model along the studied section

on the east of Ahwaz Field and also in the inter-field areas (Karimi et al. 2016a, b). According to Fig. 9, hydrocarbon migration from the Dezful Embayment to the Abadan Plain occurred at a relatively high intensity. The same was seen in Sarvak Formation in a similar direction but at a lower intensity, while the Ilam Formation had nothing to do with the hydrocarbon migration. Due to the intensity of lateral migration in sub-Kazhdumi reservoirs as well as some of the Sarvak reservoirs, the formations can have their porosity and permeability altered in the inter-field areas, increasing the chances of developing stratigraphic traps, calling for further studies. As shown in Fig. 9, the lighter the weight of the hydrocarbons produced from Kazhdumi Formation, as compared to other fluids (i.e. water), reservoir pressure, presence of vertical migration paths, and relatively high porosity of the reservoir horizons have made the produced hydrocarbon migrate vertically up into Sarvak Formation or horizontally/obliquely into Ilam and Asmari formations on top of the anticline (Zeinalzadeh and Rezaei 2010). The sealing effect of Kazhdumi Formation, however, has prevented the hydrocarbons from leaving the anticline. Ilam and Sarvak formations are dominated by highly fractured carbonates that provide for higher permeability than Pabdeh and Gurpi formations. This situation prevents the evasion of hydrocarbons across the ridges toward Pabdeh and/or Gurpi Formation. Indeed, post-migration internal movement of hydrocarbons within Ilam and Sarvak formations increased the hydrocarbon saturation along the ridge of the anticline. The increase in the saturation creates more thrusts, which together with the cracks and fissures caused on top of the anticline upon folding provide a suitable path for the vertical migration of hydrocarbons into the Asmari Formation. The absence of cracks and high saturation of the areas along the ridges limited the migration of hydrocarbons into Pabdeh and Gurpi formations (adapted from in-house reports of NIOC Exp. and the results of its modeling project).

The pressure data at the wells indicate a high-pressure zone in the reservoirs underlying the Kazhdumi Formation, especially Fahlian. In the shallower reservoirs (e.g. Asmari, Ilam and Sarvak), no sudden change was observed in the increasing trend of pressure. The Kazhdumi Formation plays two roles in the studied petroleum system, namely as source rock and cap rock, separating the former Cretaceous petroleum system from the Middle Cretaceous-Miocene one. The strength of this cap rock is so high that it can tolerate sudden changes in the pressure of the underlying reservoirs of the Cretaceous petroleum system. Figure 10 indicates the effective roles of Kazhdumi and Gutnia Formations as cap rock. Here, the Gachsaran cap rock and Pabdeh and Gurpi Formations were absent. The most important point regarding the northwest-southeast section is the distribution of the HF across the North Dezful Embayment. As revealed by 


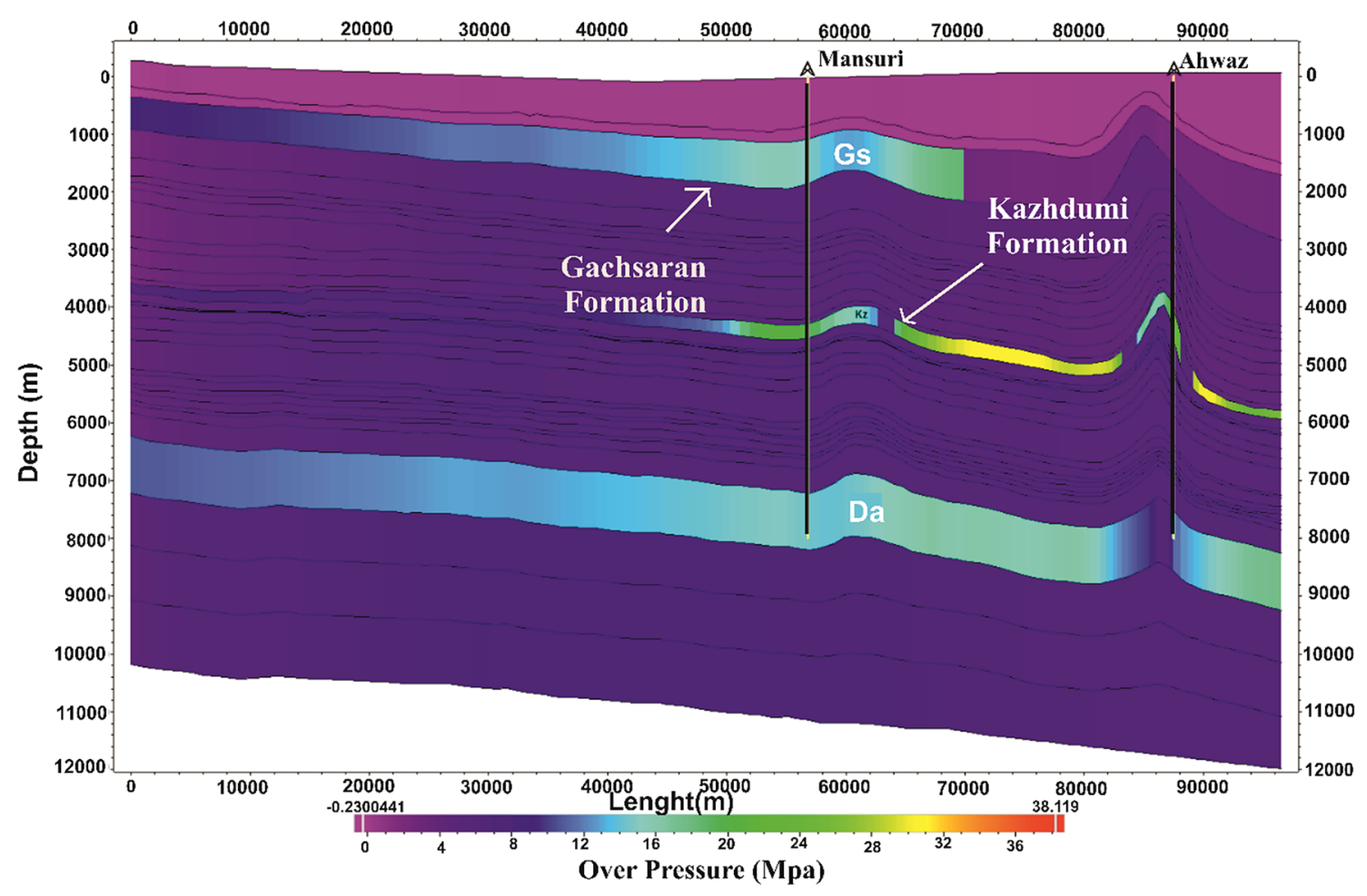

Fig. 10 High-pressure zones across the studied cross section

the results of 1D modeling and measured data at wells (e.g. temperature and vitrinite reflectance), optimal HF rate was between 44 and $50 \mathrm{~mW} / \mathrm{m}^{2}$, where the best fit between the measured data and modeling results was obtained. The HF was maximal on the anticlines and generally increased as one moved toward the Abadan Plain (Fig. 11).

\section{Conclusions}

According to the geochemical studies, it was found that, in the North Dezful Area, in contrast to the Kazhdumi, Garu and Sargelu Formations, the Pabdeh Formation is yet to be mature enough to produce hydrocarbon. In this study, 1D basin modeling was performed based on the data from four exploratory wells drilled in different fields across North Dezful, including Ab-Teymour, Band-e-Karkheh, MushtaqEast and Ramshir fields. For this purpose, the maturation and hydrocarbon production processes were investigated in the North Dezful. Well selection was done to ensure maximum drilling depth and hence enable calculations for deeper source rocks at an acceptable level of accuracy. 2D modeling was performed by defining a cross section (northeast-southwest) and then evaluating the maturity levels of kerogen (s) of different sedimentary strata.

The best fit between the measured data and modeling results was obtained with $\mathrm{HF}$ values in the range of 44 to 50
$\mathrm{mW} / \mathrm{m}^{2}$. Simultaneous calibration of temperature and vitrinite reflectance and the uniform increase in the vitrinite reflectance with depth indicated mild tectonics of the region. According to the results obtained from the 1D modeling, the Sargelu and Garu Formations were found to be in the gas window, and the Kazhdumi Formation was in the oil window, making it possible to effectively charge the regional fields, considering the timing of the Zagros Orogeny. Based on the modeling results, the OM of the Pabdeh Formation was immature, producing no hydrocarbons. The Pabdeh Formation showed an average temperature of $90{ }^{\circ} \mathrm{C}$ and vitrinite reflectance of $0.6 \%$. Dated back to Albian, the Kazhdumi and Garu Formations were found to have experienced temperatures in the ranges of $90-105^{\circ} \mathrm{C}$ and $160-180{ }^{\circ} \mathrm{C}$, respectively. Sargelu Formation was found to underwent a maximum temperature of $173{ }^{\circ} \mathrm{C}$.

The results of the migration modeling across the studied section showed that the Early Cretaceous and Middle Cretaceous hydrocarbon systems were separated by the Kazhdumi Formation, inhibiting the hydrocarbon migration into deeper layers of Kazhdumi Formation. This often leads to lateral migration of the hydrocarbons into the Abadan Plain. In the Asmari Formation, the charging was found to have occurred within the field due to the presence of faults in the fields. Our findings highlighted the changes in the temperature and maturity of the OM across different parts of the anticline. The Early and Middle Cretaceous petroleum systems were 


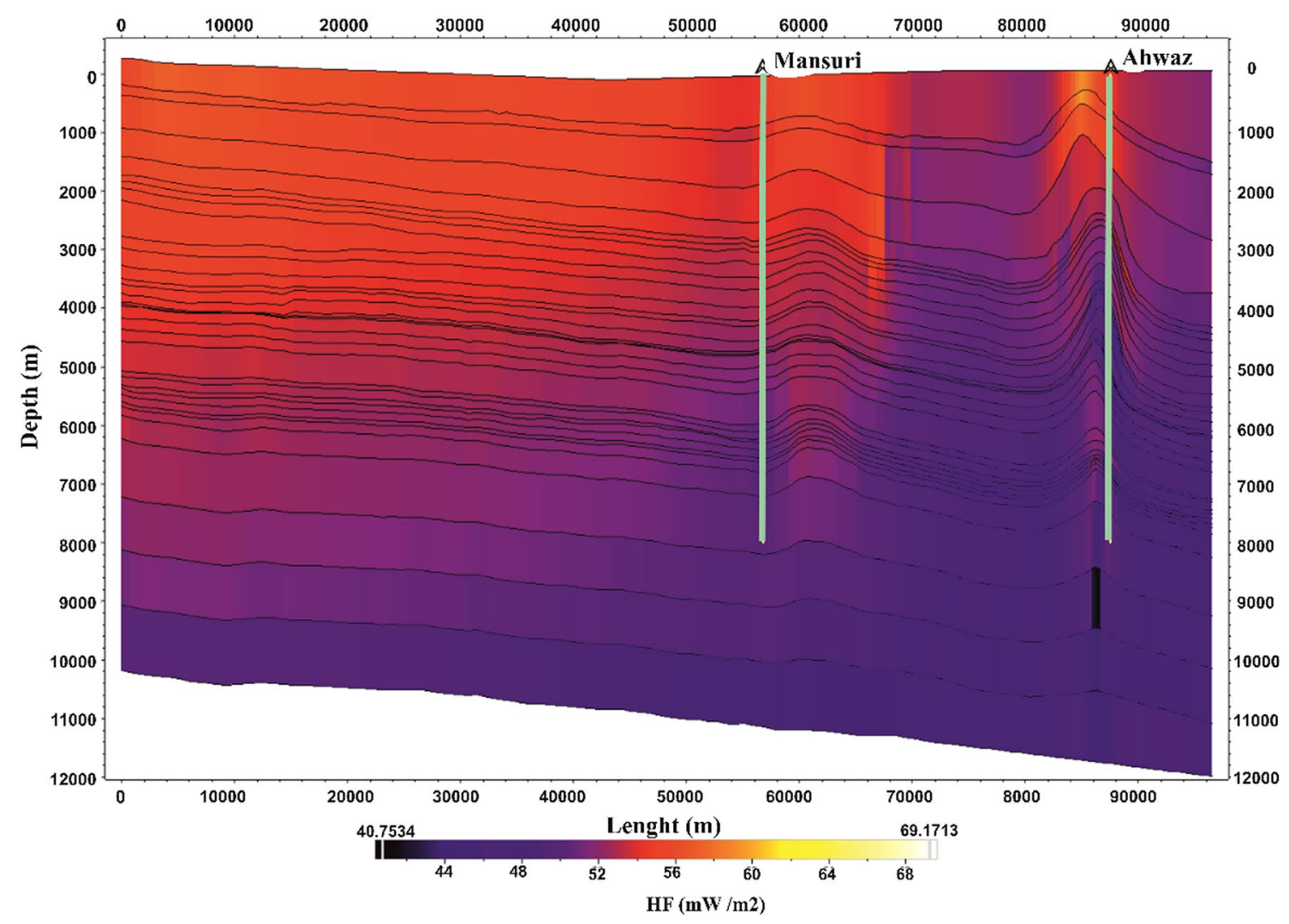

Fig. 11 Variations of HF across the cross section

found to be connected through particular geometry features or possibly faults, with the two systems separated by Kazhdumi Formation.

Acknowledgements Authors would like to appreciate Semnan University for providing the testing facilities for conducting this research.

Data availability The datasets generated and/or analyzed in the present study are not publicly available due to the data protection policies set by the original owner of the data, yet reasonable requests for such data may be considered by the corresponding author.

\section{Declarations}

Conflict of interest The authors hereby declare that they have no conflict of interest.

Open Access This article is licensed under a Creative Commons Attribution 4.0 International License, which permits use, sharing, adaptation, distribution and reproduction in any medium or format, as long as you give appropriate credit to the original author(s) and the source, provide a link to the Creative Commons licence, and indicate if changes were made. The images or other third party material in this article are included in the article's Creative Commons licence, unless indicated otherwise in a credit line to the material. If material is not included in the article's Creative Commons licence and your intended use is not permitted by statutory regulation or exceeds the permitted use, you will need to obtain permission directly from the copyright holder. To view a copy of this licence, visit http://creativecommons.org/licenses/by/4.0/.

\section{References}

Alavi M (1994) Tectonic of the Zagros orogenic belt of iran-new data and interpretations. Tectonophysics 229:211

Alavi M (2004) Regional stratigraphy of the zagros fold-thrust belt of Iran and its proforeland evolution. Am J Sci 304:1-20

Arsalan Z, Moussavi-Harami R, Mahboubi A, Sajjadian VA (2015) Basin and petroleum system modeling of the cretaceous and jurassic source rocks of the gas and oil reservoirs in darquain field, South West Iran. J Nat Gas Sci Eng 26:419-426

Baniasad A, Rabbani A, Sachse VF, Littke R, Moallemi SA, Soleimany B (2016) 2D basin modeling study of the Binak Trough, northwestern Persian Gulf. Iran Marine Petroleum Geol 77:882-897. https://doi.org/10.1016/j.marpetgeo.2016.07.025

Baur F, Littke R, Wielens H, Lampe C, Fuchs T (2010) Basin modeling meets rift analysis-a numerical modeling study from the Jeanne d'Arc basin, offshore Newfoundland. Canada Marine Petroleum Geol 27(3):585-599. https://doi.org/10.1016/j.marpe tgeo.2009.06.003

Beha A, Thomsen RO, Littke R (2008) A rapid method of quantifying the resolution limits of heat-flow estimates in basin models. J Pet Geol 31(2):167-178. https://doi.org/10.1111/j.1747-5457. 2008.00414.x

Berberian M (1995) Master "blind" thrust faults hidden under the Zagros folds: active basement tectonics and surface morphotectonics. Tectonophysics. https://doi.org/10.1016/0040-1951(94) 00185-C

Berberian M, King GCP (1981) Towards a paleogeography and tectonic evolution of Iran. Can J Earth Sci 18(2):210-265. https:// doi.org/10.1139/e81-019 
Bordenave ML (2002) The Middle Cretaceous and Early Miocene petroleum system in the Zagros domain of Iran and its prospect evaluation. In: AAPG Annual Meeting, Houston, American Association of Petroleum Geologists, pp 1-9

Bordenave ML, Hegre JA (2005) The influence of tectonics on the entrapment of oil in the Dezful Embayment, Zagros Foldbelt. Iran J Petroleum Geol 28(4):339-368. https://doi.org/10.1111/j. 1747-5457.2005.tb00087.x

Elham AH, Bahram A, Mohammad Hossein A (1390) Geochemical evaluation of source rocks and crude oils of Maroon oil field using Rock Evol pyrolysis machine (6) and gas chromatography (GC). J Earth Sci 21(82):31-38. https://doi.org/10.22071/gsj. 2011.54436 (In Persian)

Furst M (1990) Strike-slip faults and diapirism of the South-Eastern Zagros Ranges. Geol. survey Iran, Tehran

Hakimi MH, Najaf AA, Abdula RA, Mohialdeen IMJ (2017) Generation and expulsion history of oil-source rock (Middle Jurassic Sargelu Formation) in the Kurdistan of north Iraq, Zagros folded belt: implications from 1D basin modeling study. J Petroleum Sci Eng 162:852-872. https://doi.org/10.1016/j.petrol.2017.11.013

Hantschel T, Kauerauf AI (2009) Fundamentals of basin and petroleum systems modeling. Fundament Basin Petroleum Syst Model. https://doi.org/10.1007/978-3-540-72318-9

Jackson J, Rise M (1981) Basement faulting and the focal depths of the larger earthquakes in the Zagros mountains (Iran) 561-586

James GA, Wynd JG (1965) Stratigraphic nomenclature of iranian oil consortium agreement area. AAPG Bulletin 49:2182-2245. https://doi.org/10.1306/a663388a-16c0-11d7-8645000102c1865d

Jassin SZ, Goff JC (2006) Geology of Iraq; Dolin, Brno, distributed by Geol Soc. London, pp 232-225

Karimi AR, Rabbani AR, Kamali MR (2016a) A bulk kinetic, burial history and thermal modeling study of the albian kazhdumi and the eocene-oligocene pabdeh formations in the ahvaz anticline, dezful embayment. Iran J Petroleum Sci Eng 146:61-70. https:// doi.org/10.1016/j.petrol.2016.04.015

Karimi AR, Rabbani AR, Kamali MR, Heidarifard MH (2016) Geochemical evaluation and thermal modeling of the eocene-oligocene pabdeh and middle cretaceous gurpi formations in the northern part of the dezful embayment. Arabian J Geosci. https://doi. org/10.1007/s12517-016-2370-5
Kobraei M, Sadouni J, Rabbani AR (2019) Organic geochemical characteristics of Jurassic petroleum system in Abadan Plain and north Dezful zones of the Zagros basin, southwest Iran. J Earth Syst Sci 128(3):0-18. https://doi.org/10.1007/s12040-019-1082-0

Magoon LB, Dow WG (1994) The petroleum system - from source to trap. AAPG Meml 60:291

Motiei H (1995) Geology of Zagros Oil. Publications of the Geological Survey of Iran (In Persian)

Noeth S, Thomsen RO, Littke R (2002) A method for assessing statistical significance and uncertainties for calibration of 1-D thermal basin maturation models. Am Assoc Petr Geol Mem 3(3):417-431

Rabbani AR, Bagheri Tirtashi R (2010) Hydrocarbon source rock evaluation of the super giant Ahwaz oil field, SW Iran. Aust J Basic Appl Sci 4(5):673-686

Schneider F (2003) Modeling multiphase flow of petroleum at the sedimentary basin scale. J Geochem Explor 78-79:693-696. https:// doi.org/10.1016/S0375-6742(03)00092-X

Sherkati S, Letouzey J (2004) Variation of structural style and basin evolution in the central Zagros (Izeh zone and Dezful Embayment). Iran Marine Petroleum Geol 21(5):535-554. https://doi. org/10.1016/j.marpetgeo.2004.01.007

Ungerer P, Burrus J, Doligez B, Chenet PY, Bessis F (1990) Basin evaluation by integrated two-dimensional modeling of heat transfer, fluid flow, hydrocarbon generation, and migration. Am Asso Petrol Geol Bull. https://doi.org/10.1306/0c9b22db-1710-11d7$8645000102 \mathrm{c} 1865 \mathrm{~d}$

Versfelt Jr PL (2001) Major hydrocarbon potential in Iran. In: Downey MW, Threet JC, Morgan WA (eds) Petroleum Provinces of the Twenty First Century, vol 74. AAPG Memoir, pp 417-427

Welte DH, Horsfield B, Baker DR (1997) The Early and Middle Cretaceous petroleum systems were found to be connected through particular geometry features or possibly faults, with the two systems separated by Kazhdumi Formation. Pet Basin Evol. https:// doi.org/10.1007/978-3-642-60423-2

Publisher's Note Springer Nature remains neutral with regard to jurisdictional claims in published maps and institutional affiliations. 